\title{
PENGGUNAAN ENZIM CAIRAN RUMEN SEBAGAI ALTERNATIF UNTUK MENDUKUNG PEMANFAATAN BAHAN BAKU PAKAN IKAN LOKAL
}

\author{
Wahyu Pamungkas \\ Balai Penelitian dan Pemuliaan Ikan \\ II. Raya Sukamandi No. 2, Subang 41256 \\ E-mail: baginfo_Irptbpat@yahoo.com; yhoe_pamungkas@yahoo.co.id
}

\begin{abstract}
ABSTRAK
Pemanfaatan bahan baku pakan alternatif telah banyak dilakukan yaitu dengan menggunakan bahan baku pakan lokal yang mudah didapat dan biasanya berupa limbah yang belum termanfaatkan secara optimal. Namun, upaya pemanfaatan bahan baku pakan lokal tersebut masih mengalami kendala salah satunya adalah tingginya kandungan serat kasar yaitu lebih dari $7 \%$ Kandungan serat kasar yang tinggi menyebabkan bahan baku lokal tersebut perlu diolah lagi agar dapat digunakan sebagai bahan baku pakan ikan. Salah satu alternatif teknologi yang dapat digunakan adalah pemanfaatan cairan rumen untuk menurunkan kandungan serat kasar bahan pakan. Cairan rumen merupakan salah satu sumber bahan alternatif yang murah dan dapat dimanfaatkan dengan mudah sebagai sumber enzim hidrolase. Pengolahan bahan baku pakan lokal hasil limbah agro industri dan limbah peternakan menggunakan enzim cairan rumen akan dapat memberikan dampak peningkatan nilai nutrisi bahan pakan lokal sehingga dapat digunakan menjadi sumber pakan alternatif yang berkualitas.
\end{abstract}

KATAKUNCl: bahan baku pakan lokal, cairan rumen, enzim, limbah peternakan

\section{PENDAHULUAN}

Komponen terbesar dari biaya produksi pada kegiatan budidaya perikanan adalah pakan, yaitu mencapai $60 \% 70 \%$ Hal tersebut menjadi salah satu permasalahan dalam kegiatan budidaya karena harga bahan pakan konvensional, terutama sumber protein seperti tepung ikan dan bungkil kedelai, berfluktuasi dan masih harus diimpor untuk memenuhi kebutuhan industri peternakan dan perikanan. Kenyataan tersebut membawa dampak mahalnya harga pakan dan semakin tingginya biaya produksi yang harus dikeluarkan dalam kegiatan budidaya perikanan. Berbagai upaya dilakukan untuk mengatasi permasalahan bahan pakan tersebut yang salah satunya adalah dengan mencari bahan baku pakan alternatif yang tersedia secara lokal, berlimpah, dan terjaga kontinuitasnya, serta dapat menggantikan atau mengurangi penggunaan bahan pakan impor.

Pemanfaatan bahan baku pakan alternatif telah banyak dilakukan yaitu dengan menggunakan bahan baku pakan lokal yang mudah didapat dan biasanya berupa limbah yang belum termanfaatkan secara optimal. Beberapa bahan baku pakan lokal yang mempunyai potensi sebagai bahan baku pakan alternatif adalah yang berasal dari limbah industri pertanian seperti bungkil kelapa sawit, ampas sagu, bungkil biji karet, bungkil kelapa, kopra, kulit buah kakao, daun rami, limbah tanaman pisang, limbah singkong, dan dedak padi, serta limbah peternakan seperti isi rumen (Wizna et al., 2008), limbah udang, limbah bulu ayam (Cortezi et al., 2008) dan sebagainya. Akan tetapi, upaya pemanfaatan bahan baku pakan lokal tersebut masih mengalami kendala yaitu tingginya kandungan serat kasar yaitu lebih dari $7 \%$ rendahnya kandungan protein kasar bahan baku, keseimbangan asam amino yang rendah, dan adanya zat anti nutrisi.

Kandungan serat kasar yang tinggi menyebabkan bahan baku lokal tersebut perlu diolah lagi agar dapat digunakan sebagai bahan baku pakan ikan. Halver (1989) menyatakan bahwa ikan kurang mampu mencerna serat kasar karena dalam usus ikan tidak terdapat mikroba yang dapat memproduksi enzim selulase. Serat diperlukan dalam jumlah yang terbatas dalam badan ikan yaitu maksimal $7 \%$ dalam pakan (Robinson et al., 2001). Lebih lanjut dinyatakan bahwa untuk ikan-ikan catfish serat dapat digunakan dalam pakan pada level antara 3\%6\% Kandungan serat kasar yang tinggi dalam pakan akan meningkatkan jumlah limbah yang berada dalam perairan karena rendahnya tingkat kecernaan pakan.

Berbagai pengolahan terhadap bahan pakan berserat tinggi telah banyak dilakukan untuk meningkatkan efisiensi penggunaan pakan seperti pengolahan secara fisik, kimia, dan biologi atau kombinasinya (fermentasi). Pengolahan secara fermentasi dengan menggunakan 
kapang terhadap bahan pakan yang mengandung pati dan serat tinggi mempunyai suatu kelemahan di mana hifa dari kapang tersebut merupakan serat kasar sehingga kandungan serat kasar substrat tetap tinggi. Upaya lain yang telah berkembang di bidang peternakan adalah pemanfaatan cairan rumen untuk menurunkan kandungan serat kasar bahan pakan. Cairan rumen domba merupakan salah satu sumber bahan alternatif yang murah dan dapat dimanfaatkan dengan mudah sebagai sumber enzim hidrolase (Moharrery \& Das, 2002). Cairan rumen yang diperoleh dari rumah potong hewan kaya akan kandungan enzim pendegradasi serat, mengandung enzim $\alpha$-amilase, galaktosidase, hemiselulase, selulase, dan xilanase. Menurut Kung et al., 2000, cairan rumen mengandung enzim protease/deaminase yang menghidrolisis protein atau peptide, amylase yang menghidrolisis pati, selulase yang menghidrolisis selulosa, hemiselulase (xylanase) yang menghidrolisis hemiselulosa (xylan), lipase yang menghidrolisis lemak, fitase yang menghidrolisis fitat, dan lain-lain.

Pemanfaatan bahan baku pakan lokal hasil limbah agro industri dan limbah peternakan yang ditingkatkan nilai nutrisinya diharapkan akan dapat menjadi sumber pakan alternatif yang berkualitas. Dalam tulisan ini akan diuraikan pemanfaatan cairan rumen dalam meningkatkan nilai nutrisi bahan baku pakan lokal sehingga dapat dijadikan sebagai sumber bahan baku pakan alternatif untuk pakan ikan.

\section{Kendala Pemanfaatan Bahan Baku Lokal sebagai Bahan Pakan}

Pemanfaatan bahan baku pakan alternatif telah banyak dilakukan yaitu dengan menggunakan bahan baku pakan lokal yang mudah didapat dan biasanya berupa limbah yang belum termanfaatkan secara optimal. Beberapa bahan baku pakan lokal yang mempunyai potensi sebagai bahan baku pakan alternatif adalah yang berasal dari limbah industri pertanian dan perkebunan seperti bungkil kelapa sawit, bungkil biji karet, bungkil kelapa, kopra, kulit buah kakao, dan daun rami (Kamaruddin et al., 2008), serta limbah peternakan seperti isi rumen (Wizna et al., 2008), limbah udang, limbah bulu ayam (Cortezi et al., 2008), dan limbah industri seperti ampas kecap (Marzuqi et al., 2008).

Bahan baku pakan lokal mempunyai kandungan nutrisi yang potensial digunakan sebagai bahan baku pakan ternak maupun ikan. Beberapa bahan baku pakan lokal seperti bungkil inti sawit mempunyai kandungan protein antara 13,6\%17,45\%dan kandungan lemak kasar berkisar antara 17,1\%21,55\%(Sundu et al., 2003), limbah udang memiliki kandungan energi metabolis (ME) sebesar $1.190 \mathrm{kkal} / \mathrm{kg}$, protein kasar (PK) 43,4\% kalsium (Ca) 7,05\% dan fosfor (P) 1,52\%(Hartadi et al., 1997). Tepung cangkang udang mengandung protein kasar antara 35\%45\%dan berkualitas baik, di samping itu, juga mengandung mineral (kalsium, fosfor, dan magnesium).

Namun demikian, pemanfaatan bahan baku pakan lokal tersebut masih mengalami kendala yang salah satunya adalah tingginya kandungan serat kasar. Kandungan protein kasar bungkil inti sawit sekitar 11,30\%17,00\% namun kandungan lemak dan serat kasar cukup tinggi yaitu masing-masing sebesar 4,50\%17,00\%dan 16\%23\% Lemak yang tinggi akan menyebabkan ketengikan sehingga memperpendek daya simpan bahan pakan tersebut, sedangkan serat kasar yang tinggi akan menyebabkan bahan pakan sulit dicerna oleh ternak atau ikan. M enurut Wiramiharja et al. (2007), tepung bulu yang berpotensi digunakan sebagai bahan pakan ikan sumber protein mempunyai daya cerna yang rendah karena mengandung tingkat keratin yang tinggi, keras, berserabut, dan ikatan disulfide yang kuat. Hal tersebut menyebabkan perlunya pengolahan bahan baku pakan lokal tersebut sebelum digunakan sebagai bahan pakan.

\section{Serat Kasar dalam Bahan Pakan}

Serat kasar adalah penyusun utama dinding sel tumbuhan dan merupakan fraksi karbohidrat yang telah dipisahkan dengan bahan ekstrak tanpa nitrogen (BETN) yang tidak larut dalam basa dan asam encer setelah pendidihan selama 30 menit. Serat kasar terdiri atas selulosa, hemiselulosa, dan lignin yang sulit dicerna (Tillman et al., 1989).

Serat kasar dibutuhkan dalam pakan untuk membantu proses pencernaan makanan. Menurut Piliang (2006), serat kasar membantu mempercepat ekskresi sisa-sisa makanan melalui saluran pencernaan. Lebih lanjut dinyatakan bahwa dalam keadaan tanpa serat, feses dengan kandungan air rendah akan lebih lama tinggal dalam saluran usus yang dapat menyebabkan gangguan pada gerakan peristaltik pada usus besar sehingga ekskresi feses menjadi lebih lamban. Sebaliknya, pakan dengan kandungan serat kasar yang tinggi dapat menyebabkan absorbsi zat makanan berkurang dan koefisien cerna semua zat makanan menurun.

Kadar serat kasar yang berbeda pada bahan penyusun pakan dapat mempengaruhi nilai energi yang tersedia dalam pakan karena terdapat korelasi negatif antara kadar serat dalam pakan dengan energi yang tersedia dalam pakan. Semakin tinggi kandungan serat kasar pakan maka semakin rendah jumlah energi yang tersedia. Hal tersebut disebabkan serat kasar tidak mampu menyediakan energi 
yang dapat dimanfaatkan oleh ikan. Serat kasar yang berisi selulosa, hemiselulosa, dan lignin relatif sulit dicerna dan merupakan sumber energi yang rendah.

Fraksi serat diukur berdasarkan kelarutannya dalam larutan detergen netral yang membagi serat makanan menjadi Neutral Detergent Soluble (NDS) berisi isi sel yang larut dalam detergen dan Neutral Detergent Fiber (NDF) berisi dinding sel yang tidak larut dalam larutan detergen. Acid Detergent Fiber (ADF) merupakan fraksi serat yang diukur dengan cara melarutkan dinding sel (NDF) kembali dengan larutan asam. Bagian yang tidak larut dalam larutan asam tersebut yang dinyatakan sebagai ADF yang berisi lignoselulosa. Kandungan hemiselulosa merupakan selisih kandungan NDF dan ADF. Selulosa dan lignin merupakan bagian dari ADF di mana selulosa adalah bagian yang larut dalam $\mathrm{H}_{2} \mathrm{SO}_{4} 72 \%$ dan lignin merupakan bagian yang tidak larut (Van Soest et al., 1991). Skema penguraian fraksi serat disajikan pada Gambar 1.

Kemampuan ikan dalam mencerna serat kasar dibatasi oleh kemampuan mikroflora dalam ususnya untuk mensekresikan selulase (Bureau, 2000). Keterbatasan ikan dalam memanfaatkan serat berkaitan dengan ketersediaan enzim selulolitik yang terbatas dalam saluran pencernaan ikan, bahkan pada level tertentu dapat menghambat pertumbuhan ikan.

\section{Cairan Rumen sebagai Sumber Enzim}

Isi rumen merupakan limbah rumah potong hewan yang apabila tidak ditangani dengan baik dapat mencemari lingkungan. Wizna et al. (2008) menyatakan bahwa xanthophyl yang terdapat dalam isi rumen, sebagian besar terdiri atas hijauan, diduga dibutuhkan oleh pigmen kuning telur dan kulit unggas. Manfaat lain dari penggunaan isi rumen sebagai bahan pakan adalah adanya vitamin B12 sebagai faktor protein hewan yang menyebabkan isi rumen mempunyai nilai secara biologi yang sama dengan tepung ikan dan ekstrak hati. Kandungan nutrisi dari isi rumen sapi adalah 9,29\%air; 8,45\%protein kasar; 1,23\%lemak kasar; 33,53\%serat kasar; 0,20\%Ca; 0,45\%P; 16,19\%abu; dan 31,60\%NFE. Isi rumen berpotensi sebagai feed additive. Cairan rumen telah digunakan sebagai sumber inokulan dalam pengolahan silase jerami padi. Lebih lanjut dinyatakan bahwa cairan rumen pada onggok sebagai bahan baku penyusun ransum komplit dapat meningkatkan kandungan VFA (volatile fatty acid).

Rumen diakui sebagai sumber enzim pendegradasi polisakarida. Polisakarida dihidrolisis di rumen disebabkan pengaruh sinergis dan interaksi dari kompleks mikroorganisme, terutama selulase dan xillanase. Ada dua grup jenis mikroorganisme yang diyakini pada cairan rumen (liquid phase) dan yang menempel pada digesta rumen. Enzim yang aktif mendegradasi struktural polisakarida hijauan kebanyakan aktif pada mikroorganisme yang menempel pada partikel pakan.

Mikroba-mikroba rumen mensekresikan enzim-enzim pencernaan ke dalam cairan rumen untuk membantu mendegradasi partikel makanan. Enzim-enzim tersebut

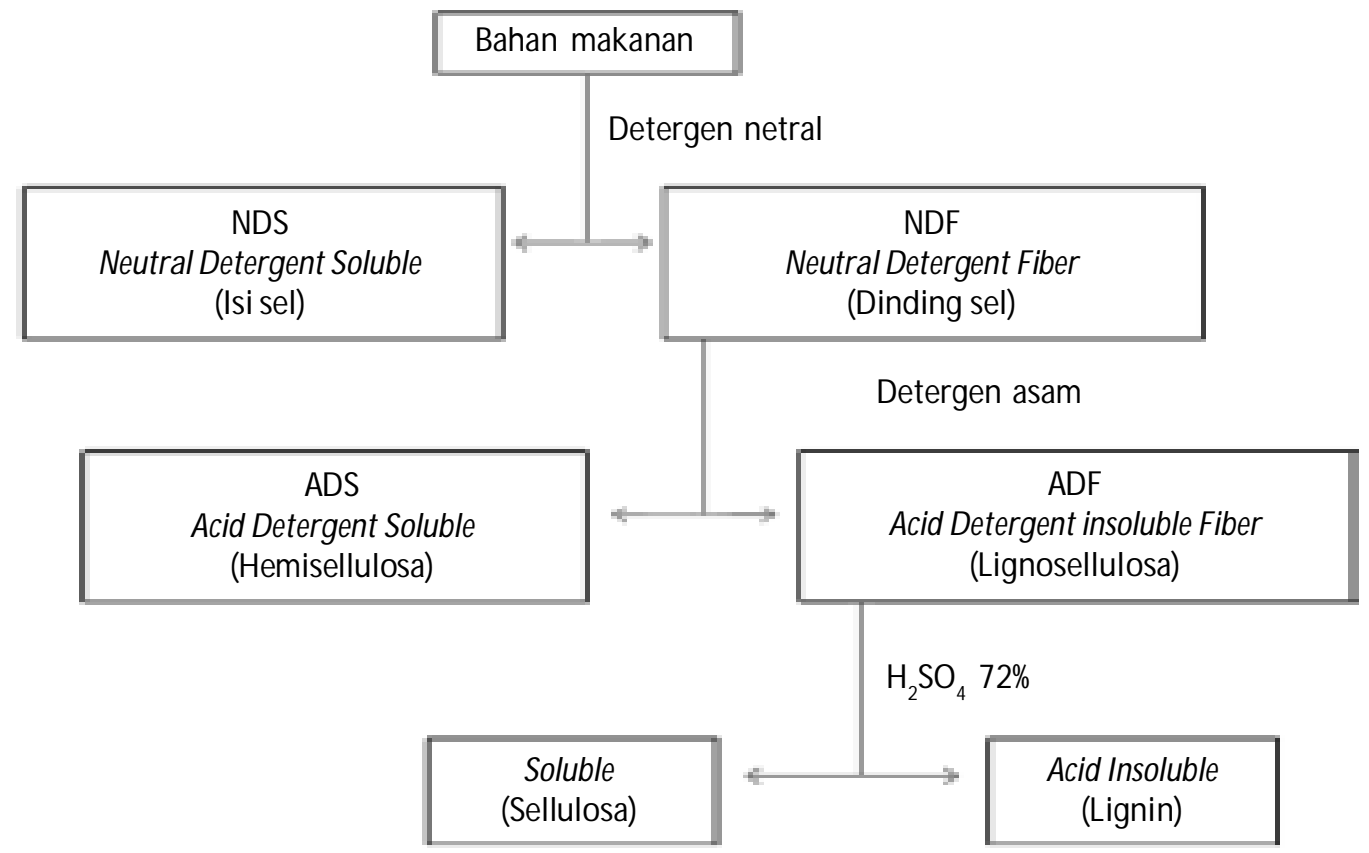

Gambar 1. Skema penguraian fraksi serat (van Soest et al., 1991) 
antara lain adalah enzim yang mendegradasi substrat selulosa yaitu selulose, hemiselulosa/xylosa adalah hemiselulase/xylanase, pati adalah amilase, pektin adalah pektinase, lipid/lemak adalah lipase, protein adalah protease, dan lain-lain. Aktivitas enzim dalam cairan rumen juga tergantung dari komposisi atau perlakuan makanan (Moharrery \& Das, 2002). Agarwal et al. (2002) melaporkan bahwa anak domba dengan bobot badan 23,5 kg yang diberi makan minum susu sampai 8 minggu dan diteruskan dengan 50\% konsentrat dan 50\% rumput sampai umur 24 minggu mendapatkan bahwa enzim-enzim yang ada dalam cairan rumen antara lain carboxymethyl celulase dengan aktivitas enzim 3,60 umol glukosa/jam/ $\mathrm{mL}$, alpha amylase 0,33 umol glukosa/menit/mL, xylanase 0,29 umol xylosa/menit/mL, beta-glukosidase $0,20 \mathrm{umol}$ p-nitrofenol $/ \mathrm{menit} / \mathrm{mL}$, alpha-glukosidase $0,008 \mathrm{~mol}$ nitrofenol/menit $/ \mathrm{mL}$, urease 0,05 umol NHs-N/menit $/ \mathrm{mL}$, dan protease $452,7 \mathrm{ug}$ hidrolisis protein/jam $/ \mathrm{mL}$. Moharrery \& Das (2002) mengukur aktivitas enzim protease, selulase, amylase, lipase, dan urease pada cairan rumen domba dan mendapatkan bahwa cairan rumen yang berisi enzim-enzim dari sel-sel bakteri, aktivitas enzimnya lebih tinggi dari cairan rumen tanpa protozoa dan tanpa sel-sel bakteri (Tabel 1).

\section{Isolasi dan Produksi Enzim Cairan Rumen}

Isolasi dan produksi enzim cairan rumen dilakukan di laboratorium yang mempunyai fasilitas sentrifuse suhu dingin. Cairan rumen diambil dari rumah pemotongan hewan (RPH) dan cairan rumen tersebut diusahakan selalu berada dalam kondisi dingin. Cairan rumen yang telah diperoleh selanjutnya segera disentrifugasi dengan kecepatan $10.000 \mathrm{rpm}$ selama 20 menit kondisi $4^{\circ} \mathrm{C}$, kemudian supernatan yang terbentuk direaksikan dengan amonium sulfat $60 \%$ dan diaduk menggunakan magnetic stirer selama kurang lebih satu jam. Cairan rumen yang telah direaksikan dengan amonium sulfat kemudian didiamkan selama 24 jam pada suhu $4^{\circ} \mathrm{C}$. Setelah disimpan selama 24 jam, selanjutnya cairan rumen disentrifugasi pada kecepatan $10.000 \mathrm{rpm}$ selama 20 menit kondisi $4^{\circ} \mathrm{C}$.
Supernatan yang terbentuk dibuang dan endapannya digunakan sebagai sumber enzim. Enzim kemudian dilarutkan dalam buffer fosfat dengan perbandingan 1:1 (endapan dari $100 \mathrm{~mL}$ supernatan cairan rumen dilarutkan dalam $100 \mathrm{~mL}$ buffer fosfat $\mathrm{pH}$ 7,0 dan disimpan pada suhu $4^{\circ} \mathrm{C}$ apabila tidak segera digunakan (Fitriliyani, 2010). Skema isolasi dan produksi enzim cairan rumen disajikan pada Gambar 2.

\section{Enzim Cairan Rumen Pendegrasi Serat dalam Bahan Pakan}

Enzim selulase, amylase, protease, dan lipase pada cairan rumen yang berisi enzim-enzim dari sel-sel bakteri mempunyai aktivitas enzim yang lebih tinggi dari cairan rumen tanpa protozoa dan sel-sel bakteri (Moharrery \& Das, 2002). Lebih lanjut dinyatakan bahwa pada cairan rumen domba bebas sel mikroba didapatkan aktivitas selulase sebesar 0,03 IU/mL/menit, sedangkan aktivitas enzim lainnya yang diperoleh adalah amilase sebesar 1,16 $\mathrm{IU} / \mathrm{mL} / \mathrm{menit}$, protease $0,22 \mathrm{IU} / \mathrm{mL} / \mathrm{menit}$, dan lipase 1,22 $\mathrm{IU} / \mathrm{mL} /$ menit. Aktivitas enzim dalam cairan rumen tergantung dari komposisi atau perlakuan makanan.

Cairan rumen telah digunakan sebagai sumber inokulan dalam pengolahan silase jerami padi dan menghasilkan penurunan bahan kering $10,6 \%$ kadar serat $15,98 \%$ serta meningkatkan kandungan protein $54,50 \%$ (Purnomohadi, 2006). Hasil penelitian Hardiyanto (2001) menyatakan bahwa cairan rumen yang ditambahkan pada onggok sebagai bahan pakan penyusun ransum komplit dapat meningkatkan kandungan VFA (volatile fatty acids). Penambahan cairan rumen sebesar 620 dan $1.240 \mathrm{U} / \mathrm{kg}$ pada wheat pollard menghasilkan penurunan kandungan polisakarida berturut-turut sebesar $4 \%$ dan 3,9\% dan kandungan polisakarida wheat pollard tanpa enzim lebih tinggi dibandingkan dengan yang ditambahkan enzim (Pantaya, 2003).

Hasil penelitian Fitriliyani (2010) yang menggunakan enzim cairan rumen domba untuk menghidrolisis tepung daun lamtoro menunjukkan adanya penurunan kandungan

Tabel 1. Komposisi enzim cairan rumen domba ${ }^{1)}$

\begin{tabular}{lccc}
\hline \multicolumn{1}{c}{ Enzim } & $\begin{array}{c}\text { Cairan rumen } \\
\text { tanpa protoz oa }\end{array}$ & $\begin{array}{c}\text { Cairan rumen } \\
\text { bebas sel mikroba }\end{array}$ & $\begin{array}{c}\text { Cairan rumen } \\
\text { dengan sel mikroba }\end{array}$ \\
\hline Selulase-Fpase (ug glukosa/mL/jam) & $738,5 \pm 3,45$ & $162,2 \pm 33,70$ & $405,30 \pm 44,19$ \\
Protease (unit/mL) & $0,201 \pm 0,078$ & $0,090 \pm 0,027$ & $0,220 \pm 0,046$ \\
Amilase (ug glukosa/menit/mL) & $172,2 \pm 45,9$ & $60,05 \pm 10,96$ & $208,7 \pm 97,0$ \\
Lipase (unit/mL) & $1,076 \pm 0,309$ & $0,339 \pm 0,080$ & $1,225 \pm 0,803$ \\
\hline 1) Enzim dari cairan rumen anak domba yang diberi makan air susu dan konsentrat sampai umur 9 minggu (Moharrery \\
\& Das, 2002)
\end{tabular}




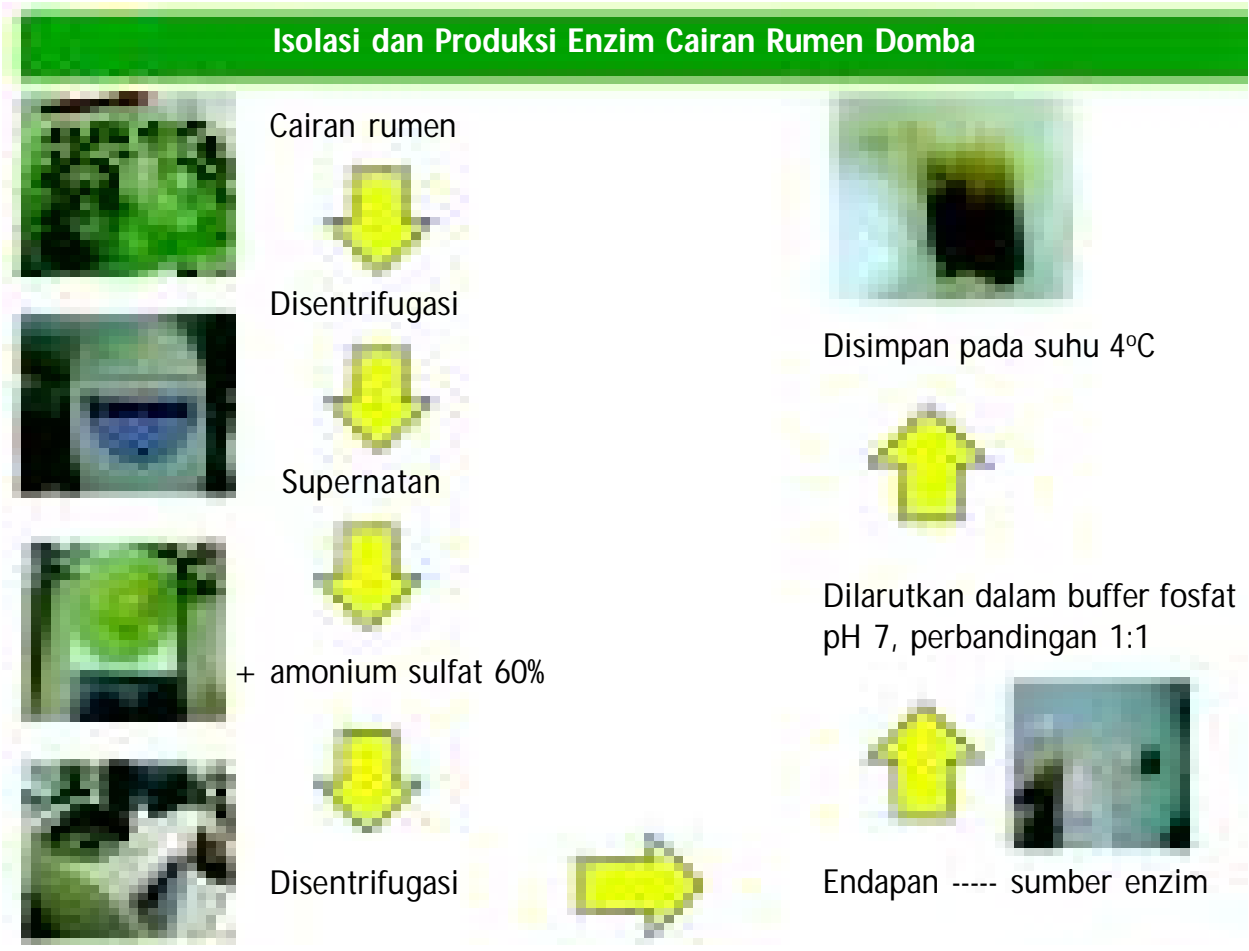

Gambar 2. Isolasi dan produksi enzim cairan rumen (Sumber: Pamungkas, 2011)

serat kasar pada penambahan enzim $100 \mathrm{~mL} / \mathrm{kg}$ bahan dengan lama waktu inkubasi 24 jam sebesar 53,64\% Penambahan enzim cairan rumen akan merombak komponen bahan yang sulit dicerna menjadi mudah dicerna yang dapat dimanfaatkan oleh hewan. Lebih lanjut dilaporkan bahwa kurva respons kadar total gula yang diukur pada inkubasi 2 jam menghasilkan kurva respons linier sedangkan periode 24 jam menghasilkan kurva respons kuadratik. Fitriliyani (2010) mengungkapkan adanya perbedaan respons tersebut di atas diduga adanya hubungan antara ketersediaan substrat dengan waktu inkubasi. Pada waktu inkubasi 2 jam jumlah substrat yang tersedia masih memungkinkan enzim untuk bekerja sedangkan pada periode inkubasi 24 jam kerja enzim sudah maksimal untuk merombak subtrat yang tersedia. Hasil penelitian Alemawor (2009) mendapatkan adanya peningkatan kualitas nutrisi yang lebih baik pada penggunaan multienzim pada bahan baku pakan dengan nilai total gula meningkat, serat kasar, NDF, ADF, selulosa, dan lignin yang menurun. Hasil penelitian Sandi et al. (2010) menunjukkan bahwa penambahan enzim cairan rumen dan bakteri Leuconostoc mesenteroides pada silase berbahan baku singkong mampu menurunkan kandungan serat kasar dan sianida pada umbi, serta meningkatkan protein bahan.

Hidrolisis bungkil kelapa sawit menggunakan enzim cairan rumen domba $100 \mathrm{~mL} / \mathrm{kg}$ bahan dengan lama waktu inkubasi selama 24 jam dapat menurunkan kandungan serat kasar bungkil kelapa sawit sebesar $56,97 \%$ dan meningkatkan nilai kecernaan bahan sampai 42,26\% (Pamungkas, 2011). Hasil penelitian Zuraida (2011) menunjukkan bahwa penambahan enzim cairan rumen domba berpengaruh nyata terhadap penurunan serat kasar bungkil kelapa. Penurunan serat kasar bungkil kelapa tertinggi diperoleh pada perlakuan volume enzim 125 $\mathrm{mL} / \mathrm{kg}$ bungkil kelapa dengan lama waktu inkubasi 24 jam yaitu dari 13,76\%menjadi 6,98\% Adapun pada hasil uji kecernaan menunjukkan bahwa kecernaan bahan (bungkil kelapa) yang telah dihidrolisis dengan enzim cairan rumen do mba sebesar $60,64 \%$ di mana nilai tersebut lebih tinggi dibandingkan dengan kecernaan bungkil kelapa tanpa dihidrolisis dengan enzim rumen yaitu $45,71 \%$ Dari hasil-hasil penelitian tersebut dapat disimpulkan bahwa penggunaan enzim cairan rumen dapat menurunkan serat kasar dan meningkatkan nilai kecernaan bahan pakan sehingga dapat digunakan sebagai bahan pakan ikan.

\section{KESIMPULAN}

Enzim cairan rumen sebagai salah satu alternatif teknologi yang dapat dimanfaatkan dalam menghidrolisis serat kasar dan meningkatkan nilai nutrisi bahan baku pakan lokal. Hal tersebut akan berdampak pada optimalisasi pemanfaatan limbah agroindustri dan 
peternakan sebagai bahan baku pakan alternatif yang mempunyai potensi untuk dikembangkan dan dimanfaatkan sebagai bahan baku pakan ikan.

\section{DAFTAR ACUAN}

Alemawor, F., Dzogbefia, V.P., Oddoye, E.O.K., \& Oldham, J.H. 2009. Enzyme cocktail for enhancing poultry utilization of cocoa pod husk. Scientific Research and Essays, 4(6): 555-559.

Agarwal, N., Kamra, D.N., Chaundhary, L.C., Agarwal, I., Sahoo, A., \& Pathak, N.N. 2002. Microbial status and rumen enzyme profile of crossbred calves fed on different microbial feed additives. Letter in Applied Microbiology, 34: 329-336.

Bureau, D.P. 2000. Feather Meals and Meat and Bone Meals From Different Origin as Protein Source in Rainbow Trout (Onchorhyncus mykis) Diets. Aquaculture, 181: 281-291.

Cortezi, M., Contiero, J., De Lima, C.J.B., Lovaglio, R.B., $\&$ Monti, R. 2008. Characterization of a feather degrading by Bacillus amyloliquefaciens.

Fitriliyani, I. 2010. Peningkatan kualitas nutrisi tepung daun lamtoro dengan penambahan ekstrak enzim cairan rumen domba untuk pakan ikan nila (Oreochromis sp). Disertasi. Program Pascasarjana. Institut Pertanian Bogor. Bogor.

Halver, J.E. 1989. Fish Nutrition. Second Edition. Academy Press Inc, New York.

Hardiyanto, S. 2001. Kecernaan (in vitro) dan kelarutan ransum komplit domba berbahan baku jerami teramoniasi dan onggok yang mendapat perlakuan cairan rumen. Skripsi. Fakultas Peternakan, Institut Pertanian Bogor.

Hartadi, H., Reksohadiprodjo, S., \& Tillman, A.D. 1997. Tabel Komposisi Pakan untuk Indonesia. Gadjah Mada University Press. Yogyakarta.

Kamaruddin, Usman, \& Tangko, A.M. 2008. Persiapan dan penyusunan bahan baku lokal untuk formulasi pakan ikan. Media Akuakultur, 3(2): 150-156.

Kung, L. Jr., Treacher, R.J., Nauman, G.A., Smagala, A.M., Endres, K.M., \& Cohen, M.A. 2000. The effect of treating forages with fibrolytic enzymes on its nutritive value and lactation performance of dairy cows. J. Dairy Sci., 83: 115-122.

Marzuqi, M., Giri, N.A., Agustina, E., \& Suwirya, K. 2008. Pengaruh tepung ampas kecap sebagai substitusi tepung ikan dalam pakan terhadap pertumbuhan dan nilai kecernaan juvenil ikan kerapu macan (Epinephelus fuscoguttatus). J. Perikanan UGM , IX(2): 254-260.
Moharrery, A. \& Das Tirta, K. 2002. Correlation between microbial enzyme activities in the rumen fluid of sheep under different treatments. Reprod. Nutr. Dev., 41: 513-529.

Pamungkas, W. 2011. Uji Efektivitas penambahan enzim cairan rumen domba terhadap penurunan serat kasar dan nilai kecernaan bungkil kelapa sawit sebagai pakan benih ikan patin siam (Pangasius hypophthalmus). Tesis. Program Pascasarjana. Institut Pertanian Bogor. Bogor, $62 \mathrm{hlm}$.

Pantaya, D. 2003. Kualitas ransum hasil pengolahan steam pelleting berbasis wheat pollard yang mendapat perlakuan enzim rumen pada broiler. Tesis. Program Pascasarjana IPB, Bogor.

Piliang, W.G. 2006. Fisiologi Nutrisi. IPB. Press. Bogor.

Purnomohadi, M. 2006. Peranan bakteri selulotik cairan rumen pada fermentasi jerami padi terhadap mutu pakan. J. Protein, 3: 108-114.

Robinson, E.H., Menghe, H.Li, \& Bruce, B.M. 2001. A practical guide to nutrition feeds, and feeding of Catfish. Bull. 1113. Mississippi Agricultural \& Forestry Experiment Station. Mississippi State University.

Sandi, S., Laconi, E.B., Sudarman, A., Wiryawan, K.G., \& Mangundjaja, D. 2010. Kualitas Nutrisi Silase Berbahan Baku Singkong yang Diberi Enzim Cairan Rumen Sapi dan Leuconostoc mesenteroides. M edia Peternakan, 33(1): 25-30.

Sundu, B., Kumar, A., \& Dingle, J.G. 2003. Perbandingan dua produk enzyme komersial pencerna beta mannan pada ayam pedaging yang mengkonsumsi bungkil kelapa sawit dengan level yang berbeda. Prosiding Seminar Nasional Pemanfaatan Sumberdaya Hayati berkelanjutan, hlm. 19-25.

Tillman, A.D., Hartadi, H., Reksohadiprodjo, S., Prawirokusumo, S., \& Lebdosoekojo, S. 1991. IImu Makanan Ternak Dasar. Cetakan ke-5. Yogyakarta: Gadjah Mada University.

Van Soest, P.J., Robertson, J.B., \& Lewis, B.A. 1991. Methods for dietary fiber, neutral detergent fiber and non-starch polysaccharides in relation to animal nutrition. J. Dairy Sci., 74: 3,583-3,597.

Wiramiharja, Y., Hernawati, R., Harahap, I.M., \& Niwa, Y. 2007. Nutrisi dan bahan pakan ikan budidaya. Freshwater Aquaculture Development Project. Balai Budidaya Air Tawar Jambi Japan International Cooperation Agency, $100 \mathrm{hlm}$.

Wizna, H., Abbas, Y., Rizal, I.P., Kompiang, \& Dharma, A. 2008. Improving the quality of sago pith and rumen content mixture as poultry feed through fermenta- 
tion by Bacillus amyloliquefaciens. Pakistan Journal of Nutrition, 7(2): 249-254.

Zuraida, D. 2011. Efektifitas penambahan enzim cairan rumen domba terhadap penurunan serat kasar dan peningkatan kecernaan bungkil kelapa sebagai pakan ikan nila merah Oreochromis sp. Tesis. Program Pascasarjana. Institut Pertanian Bogor. Bogor, 